\title{
THE SPATIAL PATTERN OF URBANIZATION AND SMALL CITIES DEVELOPMENT IN CENTRAL JAVA: A CASE STUDY OF SEMARANG-YOGYAKARTA-SURAKARTA REGION
}

\author{
J. S. Setyono ${ }^{a, b}$, H. S. Yunus ${ }^{b}$, S. R. Giyarsih ${ }^{b}$ \\ a Diponegoro University, Indonesia \\ ${ }^{b}$ Gadjah Mada University, Indonesia
}

\section{Article Info:}

Received: 10 February 2016 In revised form: 21 March 2016 Accepted: 28 April 2016 Available Online: 30 April 2016

\section{Keywords:}

Urbanization, small cities, urban system

\section{Corresponding Author:}

Jawoto Sih Setyono Gadjah Mada University, Yogyakarta, Indonesia Email: jawoto@gmail.com

\begin{abstract}
The special form of urbanization in Indonesia has led to a variety of themes on the urban development studies in Indonesia. Since 1990s, there has been an emphasis on the development of mega-urban regions, particularly those surrounding Jakarta as the biggest and the prime city in Indonesia. This research is aimed at elaborating the previous knowledge on the urbanization pattern in Indonesia, and Java in particular. More specifically, this study examines urban development trend in Central Java. The analysis of urbanization in this study can be classified into two categories, i.e. analysis of the urbanization level and analysis of the urbanization growth. These two analyses are combined by applying some GIS methods in order to understand the pattern of urbanization in the region. It is found that the urbanization process in Central Java has transformed the predominantly rural regions in the 1980s into the urban ones. The rapid growth of urban population forms some observable pattern that may be different to the national pattern. There are common spatial patterns, such as the importance of the coastal region and the essential role of the larger urban centers in the urbanization. In this regards, the emergence of the smaller centers has also contributed to the process, especially in bridging a more balanced development between major urban centers and their respective rural hinterland.
\end{abstract}

Copyright (C) 2016 GJGP-UNDIP This open access article is distributed under Creative Commons Attribution (CC-BY-NC-SA) 4.0 International license.

How to cite (APA 6th Style):

Setyono, J. S., Yunus, H. S., \& Giyarsih, S. R. (2016). The spatial pattern of urbanization and small cities development in central java: a case study of Semarang-Yogyakarta-Surakarta region. Geoplanning: Journal of Geomatics and Planning, 3(1), 53-66. doi:10.14710/geoplanning.3.1.53-66

\section{INTRODUCTION}

The study on urbanization within the context of developing countries has been of scholars' interest. There are various reasons why urbanization in developing countries attracts so many attentions. First, unlike the case in developed countries which was characterized by "urban revolution," urbanization in developing countries has different path, which to some extent is influenced by decolonization process. McGee (1971) uses the term "pseudo-urbanization" to refer to the lack of industrial basis in the urbanization (see also Armstrong \& McGee, 1985). Second, the urban growth in developing countries, most notably in Asia, has reached an unprecedented figure, even if it is compared with the urbanization in developed countries. The UN (2015) states that since 2007 the number of people living in urban areas has been more than those living in rural areas. It is estimated that by 2050 at least $65 \%$ of global population is urban dwellers. The majority of urban population in 2050 will reside in Asian and African cities (UN, 2015: 12). This figure indicates the important contribution of developing countries in the global urbanization. The third importance of urbanization in developing countries lies on the dualistic component in the urban transformation (Lo, Salih, \& Douglass, 1981; McGee, 1991). The dualism does not merely occur in economic activities in the form of formal and informal sectors, but also in the context of settlement transition as well as social change.

In this regard, like other developing countries, Indonesia has experienced the similar pattern of urbanization. Despite its common urbanization trend, Indonesia has unique characteristics rarely found in 
other developing countries. These characteristics in relation to the rural-urban transition, which is one of the key factors in urbanization. Recent studies show that the transition from rural to urban in most developing countries cannot be longer classified by only simple urban and rural dichotomy (Champion, Hugo, 2004). Urbanization process in developing countries somewhat represents the local characteristics which lead to different forms of urbanization. Fang and $\mathrm{Yu}$ (2016) state that urbanization in China is mostly influenced by the existence of urban agglomeration axes that has eventually formed certain spatial pattern of urbanization in the biggest country in the world. In India, urbanization process is mostly marked by huge migration from rural to urban areas, especially to large urban or metropolitan areas (Bhagat \& Mohanty, 2009).

Uniquely, urbanization process in Indonesia has formed in-between spatial configuration called desakota. The term is from Indonesian language that literally means "urban-rural" or "rural-urban". In his hypothetical spatial concept of Asiatica Euphoria, McGee (1991: 6) argues that desakota is a blend spatial configuration where urban functions meet the rural characteristics, especially in social-economic activities of the population living in the desakota. McGee (1989) further elaborates that with this characteristic, the urbanization in developing countries, Indonesia in particular, is more on the process of 'kotadesasi' rather than 'urbanisasi'. The use of these two Indonesian terms indicates that Indonesian urbanization has different characteristics than that of the other developing countries. According to Champion and Hugo (2004) this form of urbanization indicates a shift in urban transition which sees that urban and rural dichotomy is not sufficient to define the new forms of urbanization. Recent studies compiled by Guilmoto and Jones (2015) seem to support the proposition by analysing the current context and trend of urbanization process in China, India and Indonesia.

The special form of urbanization in Indonesia has led to thematic variation on the study of urban development in Indonesia. The earlier studies on urban development in Indonesia more focused on the social and anthropological aspects, pioneered by scholars such as Wertheim (1959) and Geertz (1963, 1965). The works of Milone $(1964,1966)$ have been one of key foundations on the urban research in Indonesia as they portrayed the trend of urban areas in Indonesia from comprehensive perspective. Rutz (1987) provided extensive explanation on the trend and type of cities and towns in Indonesia in 1980s. Since 1990s, there has been emphasis on the development of mega urban regions, particularly that refers to the region surrounding Jakarta as the biggest and the prime city in Indonesia (see Firman \& Dharmapatni, 1994; Firman, 1998, 2004, 2009). While Jakarta and its metropolitan region have been the central focus of urban studies in Indonesia, 2000s sees a slightly change in the focus of urbanization. Firman, Kombaitan, and Pradono (2007) analyze the recent dynamic of urban population in Indonesia based on census data from 1980-2006. Nas (2003) collects writings on the various themes discussing to the urban issues from cities and towns across the country.

However, along with thematic tendency to the phenomena of mega-urban formation, the study on urban development in Indonesia has also mostly taken place in Java, the most populous island in the country. Java island is around $6 \%$ of total territorial size, but is the home for more than $60 \%$ of the country's population. Evans (1984) studies the growth of urban center in Java, based on the census data from 1961 to 1980 . This is followed by two important urban studies during the period of 1980-1990 (Firman, 1992) and 1990-2000 (Firman, 2003). The later shows interesting facts about the spatial pattern of urbanization in Java. While in general the urbanization level of major districts in Java increases significantly, districts located in adjacent to bigger cities tend to grow faster than those located in the mainland of Indonesia. This finding has verified some previous hypothesis on the continuity and emergence of megaurban regions in Indonesian urbanization process.

This research aims to elaborate the previous knowledge on the urbanization pattern of Indonesia, Java in particular. Furthermore, this study examines urban development trend in Central Java. Urban studies within the context of Central Java is quite few especially when this refers to the investigation on the general trend. However, there are a lot of works on the cities within particular context (see Nas, 1989, 2003; Wouden, 1997). Greater emphasis will be given to the development of smaller urban centers. The research addresses two questions: 
1. Is there any spatial pattern that can be observed from urbanization trend in the region?

2. In relation with the development of small cities, is there any significant pattern with regard to their spatial distribution?

The remaining article is divided into four sections. The first section provides theoretical framework that underlies the analysis. This is followed by the second part which describes data used in the study and analytical framework applied to draw the conclusions. Results and discussion on research finding are elaborated in the next session. This section also tries to compare the specific result with the general urbanization process in Indonesia. The last section summarizes and concludes the discussion. A brief note on the implications of the research for policy formulation is also addressed in the final part.

\section{THEORETICAL FRAMEWORK}

In its simplest understanding, urbanization can be defined as a process of becoming urban. But in fact, the term 'becoming urban' has become uneasy concept as it can comprise different perspectives from different disciplines. The common perception on urbanization is the number of urban population living in certain geographical area (Kasarda \& Crenshaw, 1991; Yunus, 2005b). The study of urbanization in various context tends to use this concept to examine the urbanization process. However, urbanization is not merely about demographic aspect. Urbanization can also be regarded as the changes in social and economic condition and even political process (Armstrong \& McGee, 1985).

As urbanization has become multi-facets, there is divergent focus on the urbanization research, especially in the context of developing countries where differences in economic, social, and political system persist among countries. Despite its huge variation, most of urbanization research usually examines demographic or urban population transition as the basis for analysis. Within this approach, urbanization is measured by two important components, i.e. level of urbanization and urbanization growth (Kasarda and Crenshaw, 1991). Level of urbanization indicates the number of urban population in comparison with the total population. The key element of this concept is the definition of 'urban' itself, in which there are many variations in many countries (Pacione, 2009). Urbanization growth is measurement of change in urban population over time (Mc.Granahan \& Satterthwaite, 2014).

Regardless its huge variation, urbanization studies in developing countries tend to pay more emphasis on the emergence of large urban agglomeration, especially in Asian context. The topics such mega-urban regions, metropolitanization, and peri-urbanization have dominated the study of urbanization in developing countries. This focus on the one hand has advanced and enriched the development of new theoretical knowledge on global urbanization. On the other hand, however, this tendency has also limited the discussion on the other dimension of urbanization faced by many developing countries, i.e. the development of smaller urban centers. Roberts (2014) argues that there is lack of attention in small urban centers or secondary cities in study of urbanization in developing countries regardless their growing number of population.

Dix (1986) states that small cities or towns can play significant roles in development because of their uniqueness in many aspects. Rondinelli (1983) argues that the system of secondary cities can help to distribute equal development of economic resources, especially for hinterlands rural areas. With regard to their position in rural-urban continuum, Roberts (2014) further suggests that the failure to develop the appropriate function of secondary cities will affect the whole system of resource chain. As the consequences, there will be widen gap between bigger cities and metropolitan areas and with their rural counterparts. With more urban population living in urban settlement of less than 500.000 people in the coming decades (UN, 2015), the role of small cities and towns in the urbanization process of developing countries will be more significant than before.

Theoretically, the system of cities or urban system in a particular region will follow rank-size rule if there is normal distribution of cities in space (Berry, 1961, 1964). However, in the case of developing countries there has been strong tendency that the condition urban primacy is more dominant element within the urban system. The biggest city within the system grows even higher than the rests so that it dominates spatial organization of the cities. Meyer (1986) argues that the imbalance in urban system is normal as it is 
part of stages of urban system development. In fact, as Roberts (2014) points out, urban primacy occurs and characterize the development of urban system in many part of the globe, especially in developing countries. Roberts (2014: 44) further states that most of developing countries have "strong primacy" while developed countries tends to have more dispersed distribution of cities within their system. This indicates that the domination of large urban region still prevails in most country in the world.

\section{DATA AND METHODS}

This research is based on the census data published by Indonesian Central Bureau of Statistics (CBS). CBS publishes the census results in the form of aggregative data ranging from national, province, and district levels. In addition to that form, there is other publication called Village Potentials (or Potensi Desa/PODES) which provides various data at village level. Although there has been change in the concept of urban area under the CBS scheme, the use of village data is widely accepted for urban analysis in Indonesia (see Firman, Kombaitan, \& Pradono, 2007; Mulyana, 2014; Rietveld, 1988). This research uses the PODES data that are resulted from Population Census of 1990, 2000, and 2010 respectively. The data are classified into three level, i.e. provincial, district, and sub-district levels where particular type analysis of urbanization will be applied.

The analysis of urbanization in this study can be classified into two categories. The first category is the analysis of urbanization level. In this analysis, number of urban population is compared with total population in certain unit of analysis (see Yunus, 2005a, 2005b). Definition and delineation of urban area used in this research adopts the concept of urban classification developed by CBS and widely used in urban analysis in Indonesia (Mulyana, 2014). The second analysis is urbanization trend or growth, which calculate the annual growth rate of urban population. This analysis use data from population census of 1990 and 2010. The results of the two analyses then mapped by using ArcGIS software. Interpretation of the results is done by discussing the findings with previous research, especially those of Firman's works (Firman, 1992, 2003).

\section{RESULTS AND DISCUSSSION}

The following sections elaborate and discuss the urbanization pattern in Central Java. The analysis is divided into three themes. The first analysis is done by comparing urbanization level and urbanization rate or growth at provincial level. This classifies districts into different categories based on the urbanization indicators as mentioned above. The second analysis elaborates the differentiation within smaller unit, which is sub district. Analysis is done by taking Semarang-Yogyakarta-Surakarta Region (Joglosemar) as the focus of analysis. The analysis focuses on the development of smaller urban centers in the region. Four districts (kabupatens) are taken as case study.

\subsection{Urbanization Pattern in Central Java}

According to latest census data (2010), central part of Java island (Central Java Province and Yogyakarta Special Region, respectively) experiences high urbanization growth, especially in the last decade (2000-2010). The urbanization growth in that period is $4.75 \%$ per year. Compared to the national urban population growth in the same period, the urbanization growth of the region in higher (Firman et al., 2007). If the growth of urban population is expanded up to twenty years from 1990 to 2010, the number is lower. In that period, urban population growth of the region is $2.91 \%$ annually. Central Java Province and Yogyakarta experience a slightly different figure.

As shown in Table 1, urban population growth in Central Java has been always far higher compared to the total population growth. The number may be paradox, as the high growth of urban population is followed by the decreasing population growth. In the period of 1990-2010, total population increases by $0.81 \%$ per year, while in the same period the number of urban population grows steeply by $4.75 \%$. The figures indicate that there has been urban explosion in the region. In 2010, at least 13.5 million of the total population is urban population, while in Yogyakarta around 2.3 million population live in urban areas. 
Table 1. Urban and Total Population Growth in Central Java (CBS, 2011)

\begin{tabular}{cccccccc}
\hline & $\mathbf{2 0 0 0 - 2 0 1 0}$ & $\mathbf{1 9 9 0 - 2 0 0 0}$ & $\mathbf{1 9 9 0 - 2 0 1 0}$ & $\mathbf{2 0 0 0 - 2 0 1 0}$ & $\mathbf{1 9 9 0 - 2 0 0 0}$ & 0.91 \\
\hline Central Java & 4.78 & 1.06 & 2.90 & 0.70 & 0.81 \\
Yogyakarta & 4.55 & 1.35 & 2.94 & 0.43 & 0.34 \\
Total & 4.75 & $\mathbf{1 . 1 0}$ & $\mathbf{2 . 9 1}$ & $\mathbf{0 . 6 8}$ & $\mathbf{0 . 9 5}$ \\
\hline
\end{tabular}

Figure 1. Spatial Pattern of Urbanization Rate in Central Java Region 1990-2010 (Authors, 2016)

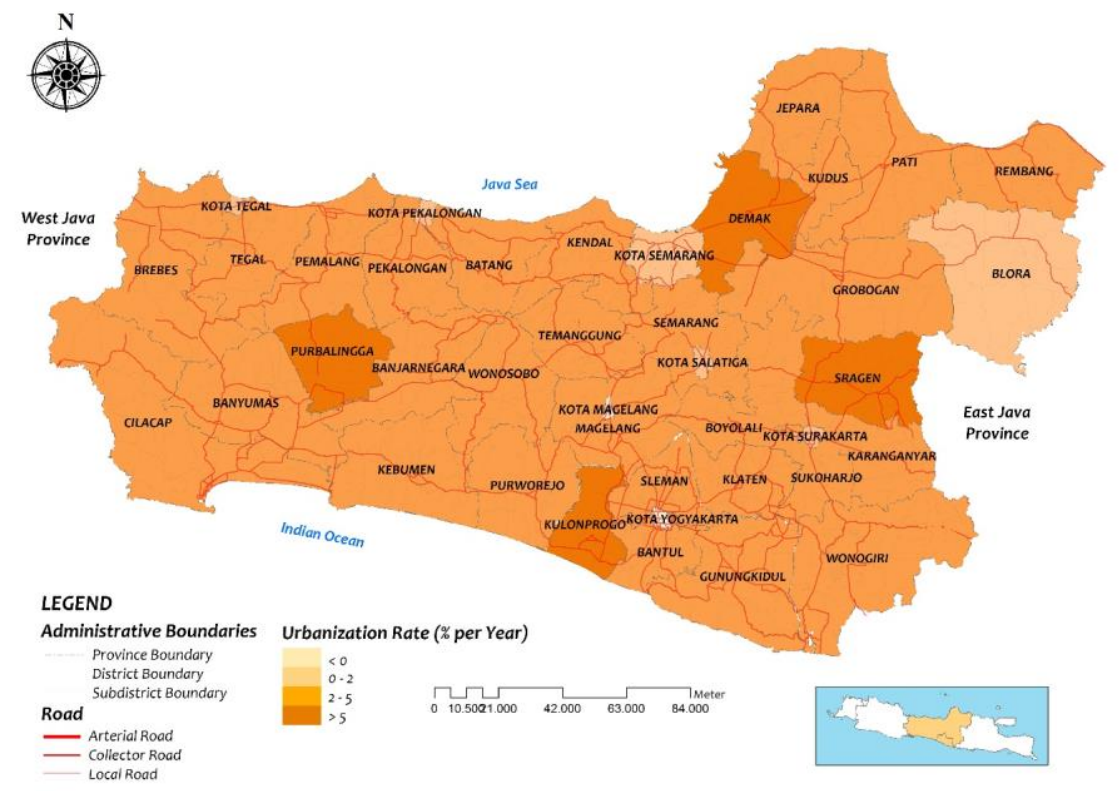

It is also interesting that there is unclear spatial pattern of urbanization growth if it is broken down into district level. As depicted in Figure 1, there are four districts which experience high urban population growth, i.e. Purbalingga, Kulonprogo, Sragen, and Demak. On the other end, one district (Rembang) and all municipalities seem to be slower than the rest of the region. However, these could imply that the regions which are remote or frontier start to become more urban in the last two decades, while the existing large cities or municipalities have low level of urban growth. While it may be too early to state that there is urban transition in regions which are predominantly agriculture, the figures enhance argument that urban population growth in bigger cities in Java tends to decline in the last two decades or so (Firman, 2003).

Another important component to comprehend urbanization process is urbanization level, which measure whether a region is urbanized or not. Table $\mathbf{2}$ shows changes of urban and rural population in the region. In 2010, Central Java region has 43\% of urban population, a significant increase compared to 2000. Period from 1990 to 2000 sees higher increase in urban population in the region, an addition of more than $10 \%$ during that period. Yogyakarta is increasingly urban in the last two decades, while Central Java remains rural region in general. This is condition is worthy for further analysis why Yogyakarta which located in down south is becoming urban. The brand name of Yogyakarta as the center of Javanese culture as well as the major tourist attraction in the country may contribute to this transition. Rotgé et al. (2000) extensively examine the importance of rural and urban integration as the main driver of higher level of urbanization in Yogyakarta.

Table 2. Proportion of Urban and Rural Population in Central Java (CBS, 2011; Firman, 2003)

\begin{tabular}{cccccccc}
\hline \multirow{2}{*}{ Province } & \multicolumn{2}{c}{2010} & & \multicolumn{2}{c}{2000} & \multicolumn{2}{c}{1990} \\
\cline { 2 - 8 } & Urban & Rural & Urban & Rural & Urban & Rural \\
\hline Central Java & 40.71 & 59.29 & 40.40 & 59.60 & 26.98 & 73.02 \\
Yogyakarta & 66.47 & 33.53 & 57.70 & 42.30 & 44.43 & 55.57 \\
Total & $\mathbf{4 3 . 1 3}$ & $\mathbf{5 6 . 8 7}$ & $\mathbf{4 1 . 9 7}$ & $\mathbf{5 8 . 0 3}$ & $\mathbf{2 8 . 6 0}$ & $\mathbf{7 1 . 4 0}$ \\
\hline
\end{tabular}


Yogyakarta and its adjacent districts have been more urban regions compared to the rest of the region. In 1990, urbanization level in Yogyakarta was smaller than Semarang, which had highest level of urbanization in that period. Twenty years later, Yogyakarta becomes one of the three biggest urban regions in Central Java, along with Semarang and Surakarta. Other interesting phenomenon is the emergence of the corridor region that connects Yogyakarta and Surakarta as a growing urban region. As shown in Table 3 and Figure 2, Klaten has transformed to be the most urbanized district in the region. The geographical position between two major centers in Central Java has influenced the region to be more urbanized in the last two decades. As Giyarsih (2010) argues, proximity and accessbilility to major arterial road linking Yogyakarta and Surakarta has transformed the previously rural areas into urban areas in the district.

Analyzing geographical feature of urbanization process in Central Java leads to some important findings. While it is obvious that southern coastal region of Central Java remains rural until 2010, it grows faster than the rest of the regions. Northern coastal region where the most important national highway is located is still growing even though it tends to slow down in the last decade (Firman, 2003). As shown in Table 3, in 2010 the level of urbanization in the norther regions reaches $49 \%$, which means that almost half of population in the region is urban population. However, it also experiences lower urbanization rate as it is below the regional average. In addition to that, Figure $\mathbf{2}$ further describes there are four important major centers in the norther region. Tegal and Pekalongan in the west along with Kudus-Jepara in the east have transformed to be more important urban region in the region.

Table 3. Geographical Pattern of Urban Population in Central Java (Authors, 2016)

\begin{tabular}{|c|c|c|c|c|}
\hline \multirow{2}{*}{ Region } & \multicolumn{2}{|c|}{ Population (2010) } & \multirow{2}{*}{ Urbanization level (2010) } & \multirow{2}{*}{ Urbanization rate $(1990-2010)$} \\
\hline & Total & $\%$ & & \\
\hline Southern coastal region & $6,526,501$ & 17.66 & 31 & 3.01 \\
\hline Inland region & $17,406,135$ & 47.09 & 43 & 2.95 \\
\hline Northern coastal region & $13,031,811$ & 35.25 & 49 & 2.83 \\
\hline Total & $36,964,447$ & 100.00 & 43 & 2.91 \\
\hline
\end{tabular}

Figure 2. Level of Urbanization in Central Java Region in 2010 (Authors, 2016)

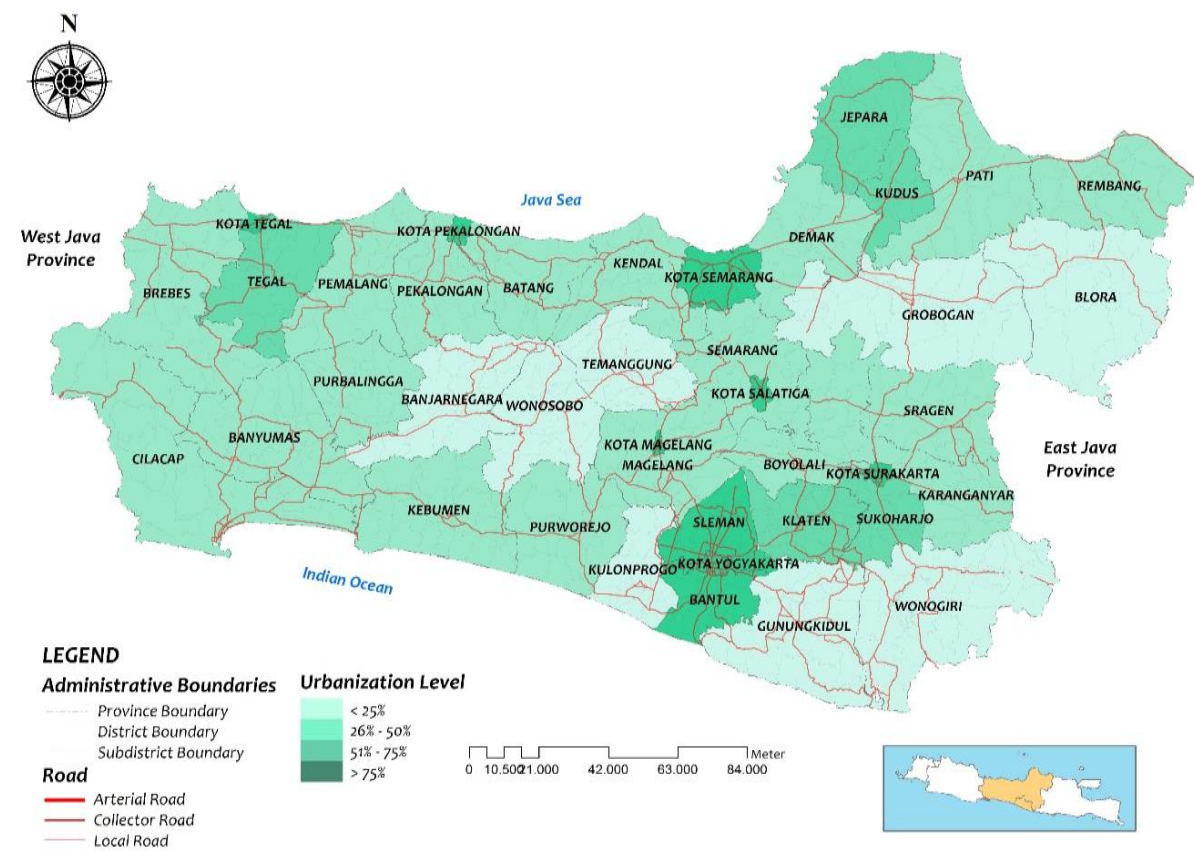


Combining two elements of urbanization into cross-section analysis provides a more interesting fact. There has been tendency that urbanization in Central Java is more characterized by the transformation from predominantly rural region to more urban region rather than a steady growth of the established urbanized regions. As depicted in Figure 3, the urban regions tend to experience the slower growth of urbanization process. This negative relation, if continuing, will imply to some significant findings. First, the characteristic of urbanization in the region is more in-situ urbanization, where urbanization takes place in the form changing rurality rather than moving population to larger urban areas. Second, the tendency of larger urban region stagnation reveals the capacity of the urban regions to even develop in the future. On the other words, the urban regions have a certain capacity which is perhaps already reached.

If the trend of the urbanization pattern continues in the future, the region will experience more balanced urbanization process. On the one hand, it is important part towards sustainable urbanization as there is only little discrepancies between regions. On the other hand, however, the trend also raises critical question about the future existence of rural production areas. This can associate with the continuing food production and supply. When most predominant rural region transforms into urban region, it implies the high rate of agricultural land conversion into more urban function. One of the obvious consequences is the decline of food production capacity which in the long term can imply to food insecurity in the region, which is previously known as one of food baskets in the country.

Figure 3. Relation between Urbanization Level and Growth in Central Java (Authors, 2016)

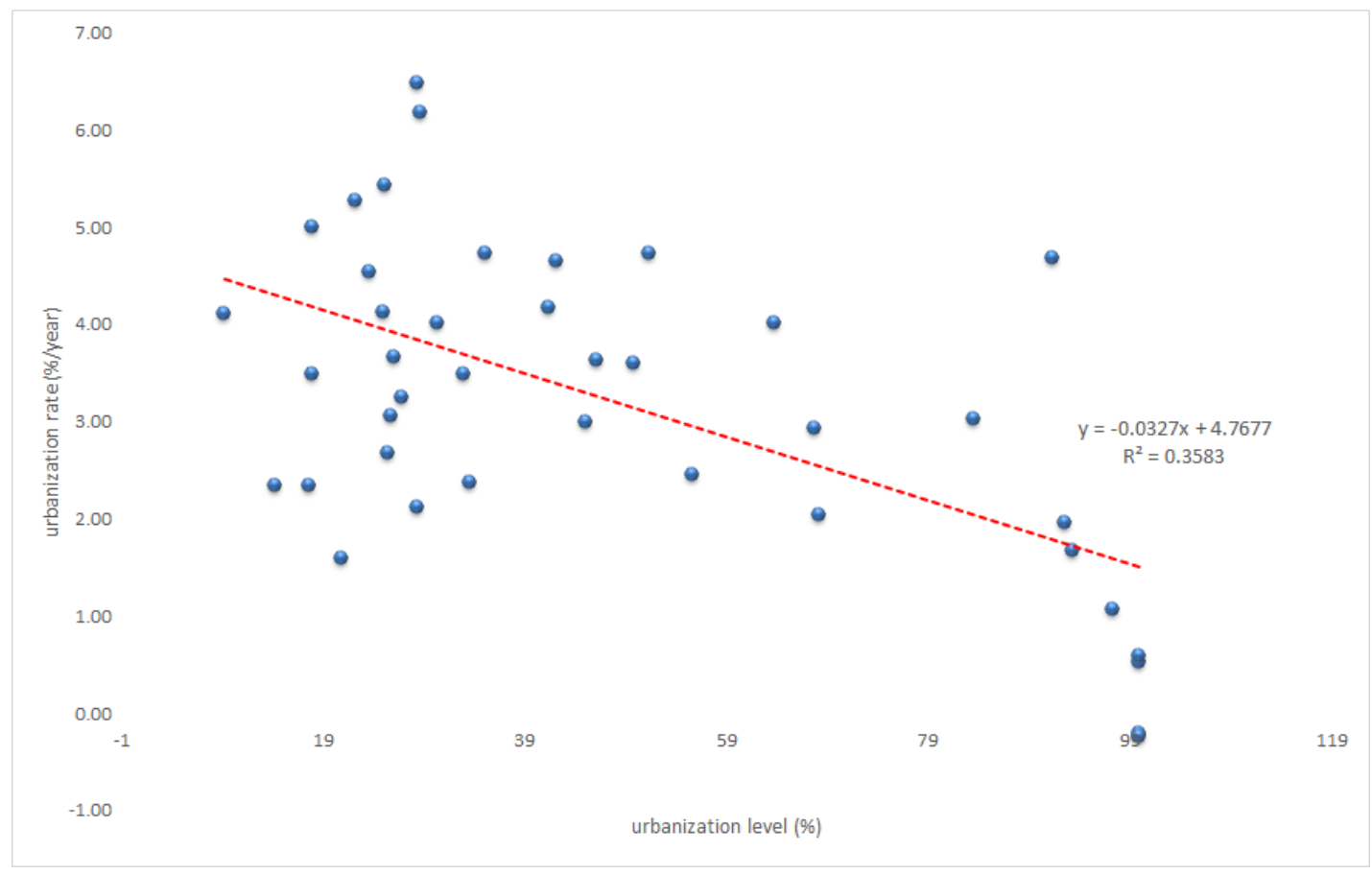

\subsection{Urbanization and Small Cities in Joglosemar Region}

Semarang-Yogyakarta-Surakarta region is locally well-known as Joglosemar (stands for Jogyakarta-Solo (old name of Surakarta)-Semarang). While there is widely accepted delineated boundary of this region, this research uses 14 districts (5 municipalities and 9 kabupatens) as study area (see Figure 4). Total population of the region accounts around one third of combined population of Central Java Province and Yogyakarta Special Region. In 2010, more than 11.6 million people live in the region (see Table 4). The region is also major economic driver of the whole central part of Java Island. In Indonesian National Spatial Planning (RTRWN) Semarang is designated as one of National Activity Centers in the island along with Jakarta and Surabaya. Firman (1992) points out that the growth triangle of Joglosemar is one of growing mega urban regions in Java. 
Figure 4. Administrative Boundary of Joglosemar Region (Authors, 2016)

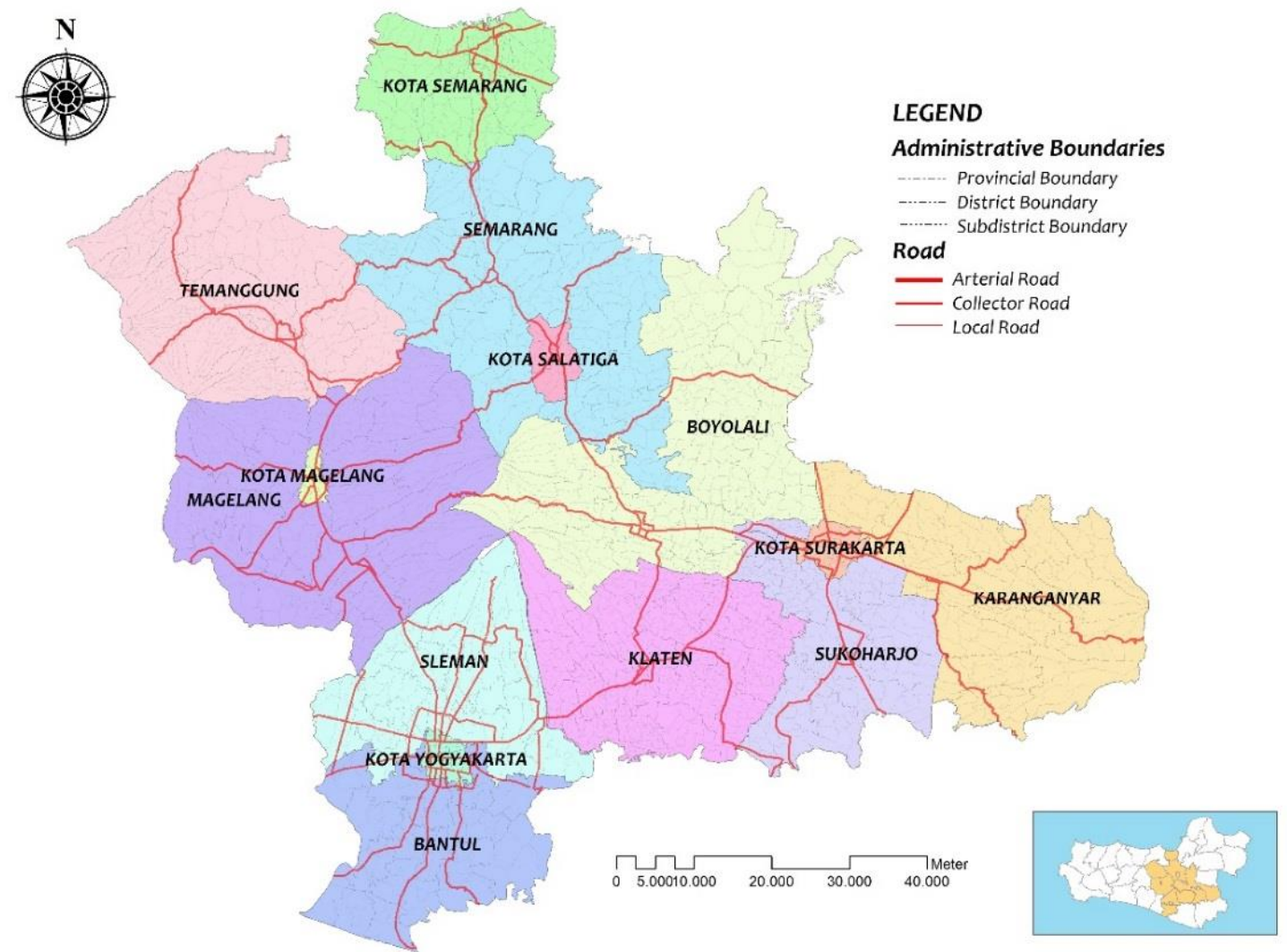

Table 4. Urban Population in Joglosemar Region (CBS, 2011)

\begin{tabular}{|c|c|c|c|c|c|}
\hline District & Population (2010) & $\begin{array}{c}\text { Population } \\
\text { growth } \\
\text { (1990-2010) }\end{array}$ & \% Urban Population (2010) & $\begin{array}{l}\text { Urbanization level } \\
\text { (2010) }\end{array}$ & $\begin{array}{c}\text { Urbanization growth } \\
(1990-2010)\end{array}$ \\
\hline Bantul & 917,694 & 1.39 & 84 & 61 & 3.03 \\
\hline Boyolali & $1,012,735$ & 0.91 & 26 & 15 & 3.67 \\
\hline Karanganyar & 877,019 & 1.15 & 42 & 21 & 4.65 \\
\hline Klaten & $1,323,513$ & 0.99 & 64 & 35 & 4.01 \\
\hline Magelang & $1,190,419$ & 0.80 & 26 & 17 & 3.06 \\
\hline Magelang City & 118,294 & -0.20 & 100 & 100 & -0.20 \\
\hline Salatiga City & 171,416 & 1.03 & 93 & 77 & 1.95 \\
\hline Semarang & 933,764 & 1.14 & 35 & 18 & 4.72 \\
\hline Semarang City & $1,500,268$ & 0.92 & 93 & 80 & 1.68 \\
\hline Sleman & $1,094,218$ & 1.70 & 91 & 51 & 4.67 \\
\hline Sukoharjo & 852,279 & 1.19 & 68 & 48 & 2.92 \\
\hline Surakarta City & 559,318 & 0.52 & 100 & 100 & 0.52 \\
\hline Temanggung & 746,093 & 0.96 & 24 & 12 & 4.54 \\
\hline Yogyakarta City & 393,080 & -0.24 & 100 & 100 & -0.24 \\
\hline Total & $11,690,110$ & 1.00 & 62 & 45 & 2.62 \\
\hline Central Java & $33,490,562$ & 0.81 & 41 & 27 & 2.90 \\
\hline
\end{tabular}

During 1990-2010 period, population growth in the region is slightly higher than that of Central Java as a whole. On average, the region population grows $1 \%$ per year in the last two decades (see Figure 5 ). In 
general, population growth of the districts in the region is more than the average figure, with exception of two cities, i.e. Yogyakarta and Magelang. These two cities experience negative population growth in that period. This phenomenon is interesting as it could indicate population migration from inner city to its adjacent suburban or peri-urban areas, which are located within other district administrative boundary. Furthermore, this fact could also imply the peri-urbanization process that already points out by some scholars (see Firman, 2003).

Figure 5. Urbanization Rate in Joglosemar Region 1990-2010 (Authors, 2016)

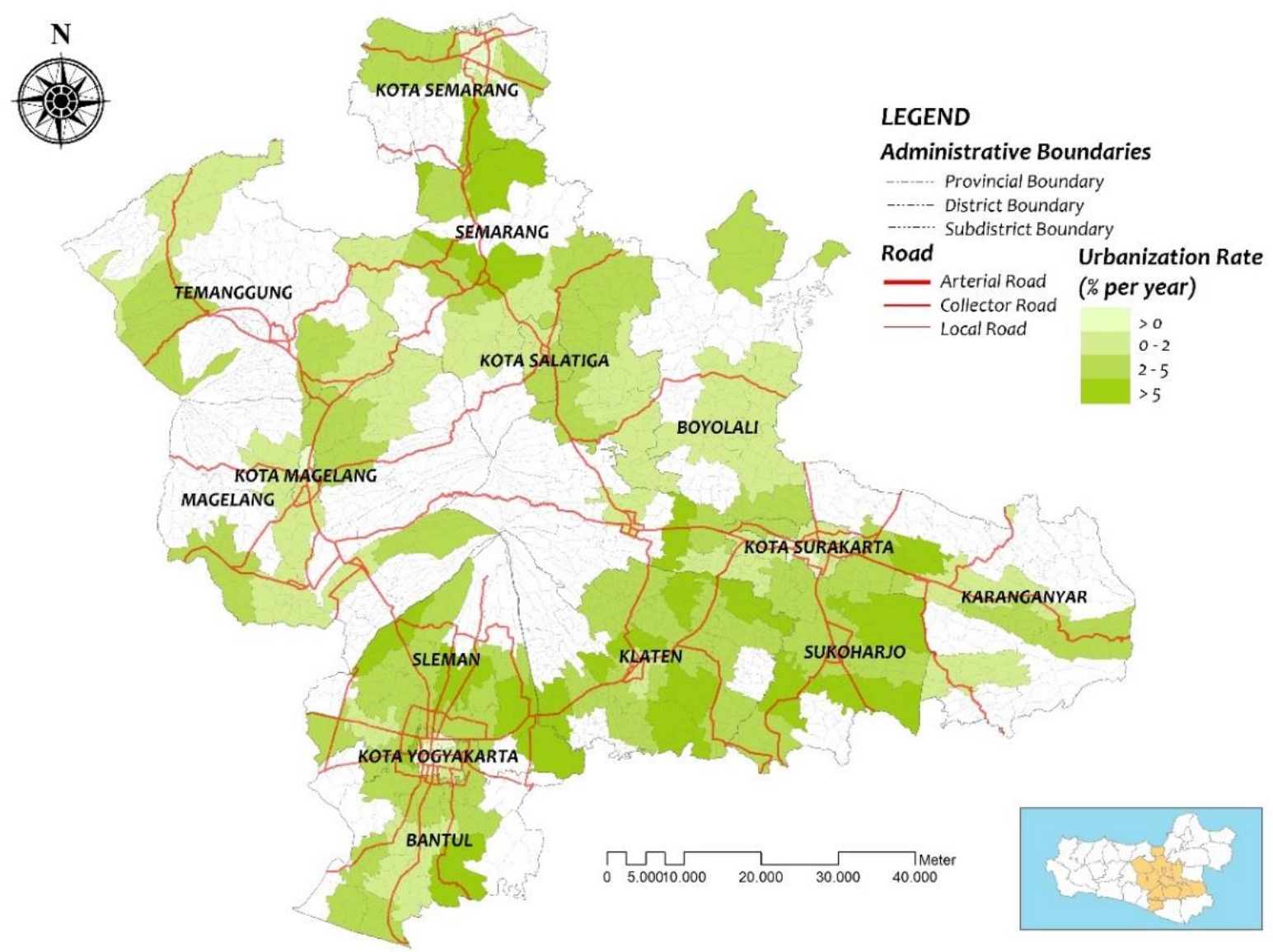

In Joglosemar region, urbanization process generally undergoes in three major centers and their surrounding hinterlands. As shown in Figure 5 and Figure 6 respectively, it obvious that Yogyakarta and Surakarta have transformed to be very big urban region. Yogyakarta and its neighboring districts of Sleman and Bantul have 2,159,410 of urban population, while Surakarta and its surrounding districts of Karanganyar and Sukoharjo have urban population of 1,505,709 people. When the urban population of Klaten is combined then this regional corridor is inhabited by more than 4.5 million people. This transformation will likely be continuing in the future because the growing economic activities contributed by tourism and related sectors.

Aside from the development of Yogyakarta-Surakarta corridor, higher urbanization rate also occurs in the sub-districts which are located along major arterial road connecting the three major centers. The existent of major roads contributes the development in region and provide better accessibility to higher urban center. Giyarsih (2010) argues that proximity to road network is one of key important determinants to the spatial transformation in region. This development is likely advancing further as the governments are starting to construct new toll road network which was planned to link Semarang and Surakarta. This highway which is part of planned Trans-Java toll network will even move forward the process of urbanization in the corridor. When the project is completed in 2019 , the same situation as happened in Yogyakarta-Surakarta corridor will be so in the Semarang-Surakarta corridor. 
Figure 6. Urbanization Level of Joglosemar Region in 2010 (Authors, 2016)

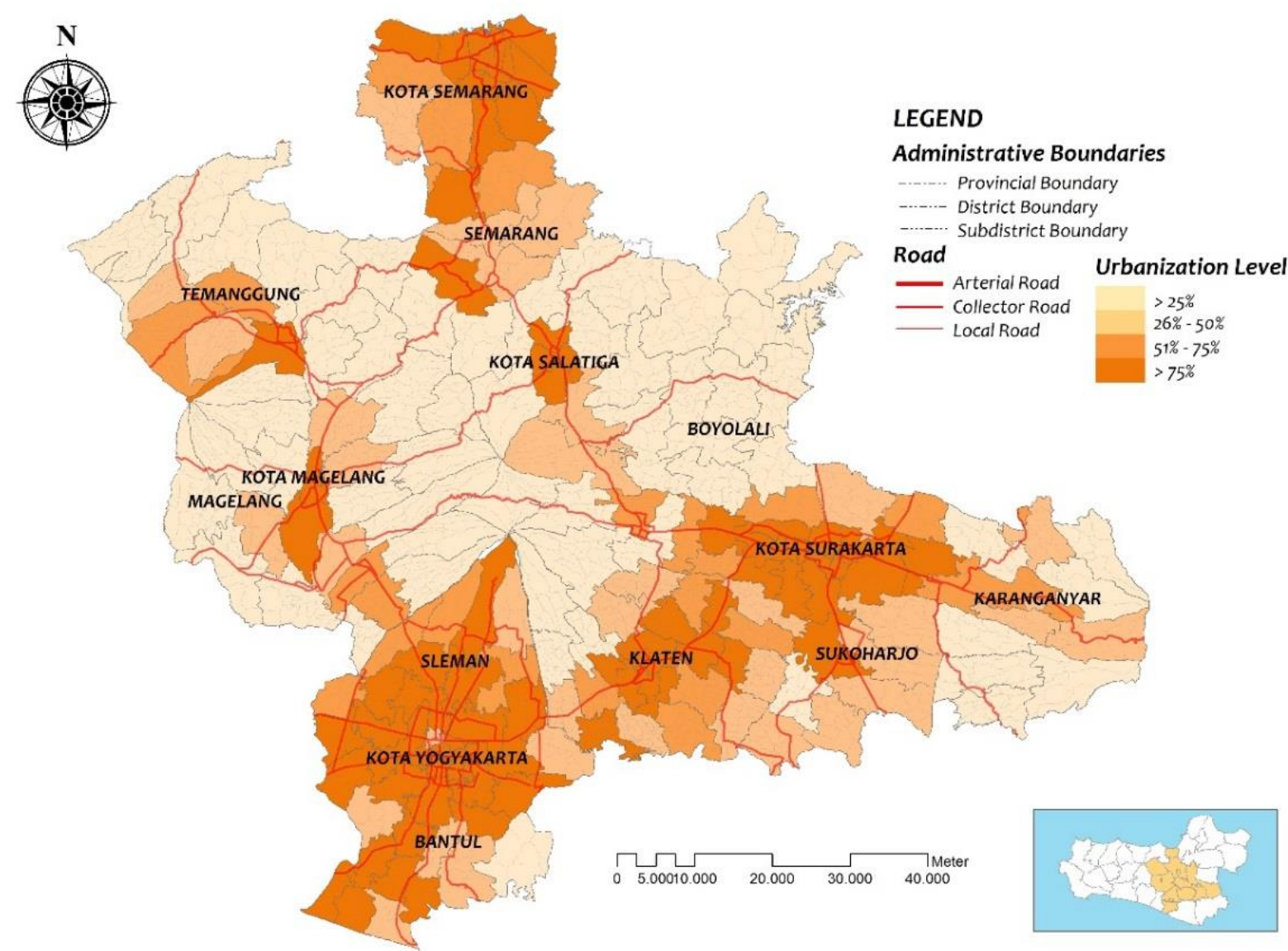

While the emergence of mega-urban region of Joglosemar is underway, it is important to pay attention on the development small urban centers within region. By using sub-district administrative boundary as the basis for analysis, there are 111 urban areas in the Joglosemar region whose population is more than 10,000 inhabitants (Table 5). Semarang and other four municipalities (Yogyakarta, Surakarta, Magelang and Salatiga) are among the highest hierarchy in the distribution. In 2010, urban areas which have population of 100,000 people or more only contribute less than half of the total urban population, while $57 \%$ of the total urban population are smaller urban centers. There is significant increase in number of urban population in smaller urban centers compared to 1990. Furthermore, the number of small cities also increases during the last two decades, from 55 cities in 1990 to 101 in 2010. This fact suggests that urbanization process in the region has been characterized by the emergence of smaller urban centers. This also indicates the growing economic activities in rural areas which lead to development of small center for rural region. Moreover, this is also one of indicators of a more balanced urbanization process in the region.

One of the common pattern of urbanization process in developing countries is the tendency of high degree of urban primacy (see Armstrong \& McGee, 1985; Kasarda \& Crenshaw, 1991; Potter \& Lloyd-Evans, 2014). While it may be the case for the entire central part of Java region, in Joglosemar region there seems to be different condition. As shown in Figure 7, distribution of urban areas or cities in the region is classified as normal, when it is either measured by absolute or logarithmic distribution. Semarang and the other major centers indeed have experienced certain growth which is quite normal regarding to their historical development as one of the early urban centers in Java island. However, the growth of largest urban center in the region has not created 'core-periphery' dichotomy; rather it spreads out the development to the hinterland. As van der Wouden (1997) argues that small towns and cities in Central Java have their own dynamics which place them at the important position for their respective hinterlands (see also Titus, 1991). 
Table 5. Urban Population Distribution in Joglosemar Region 1990-2010 (Authors, 2016)

\begin{tabular}{|c|c|c|c|c|c|c|}
\hline \multirow{2}{*}{ Population Size } & \multicolumn{2}{|c|}{ Total Population } & \multicolumn{2}{|c|}{ Proportion (\%) } & \multicolumn{2}{|c|}{ Number of Urban Areas } \\
\hline & 2010 & 1990 & 2010 & 1990 & 2010 & 1990 \\
\hline$>1$ million & $1,373,697$ & 0 & 19 & 0 & 1 & 0 \\
\hline $500,000-1,000,000$ & 559,318 & $1,435,439$ & 8 & 36 & 1 & 2 \\
\hline $100,000-500,000$ & $1,295,940$ & 749,828 & 18 & 19 & 8 & 4 \\
\hline $50,000-100,000$ & $1,464,755$ & 431,863 & 20 & 11 & 21 & 7 \\
\hline $20,000-50,000$ & $2,064,027$ & 982,433 & 28 & 25 & 60 & 32 \\
\hline $10,000-20,000$ & 643,935 & 357,101 & 9 & 9 & 20 & 26 \\
\hline Total & $7,401,672$ & $3,956,664$ & 100 & 100 & 111 & 71 \\
\hline
\end{tabular}

Figure 7. Rank Distribution of Urban Areas in Joglosemar 2010 (Authors, 2016)
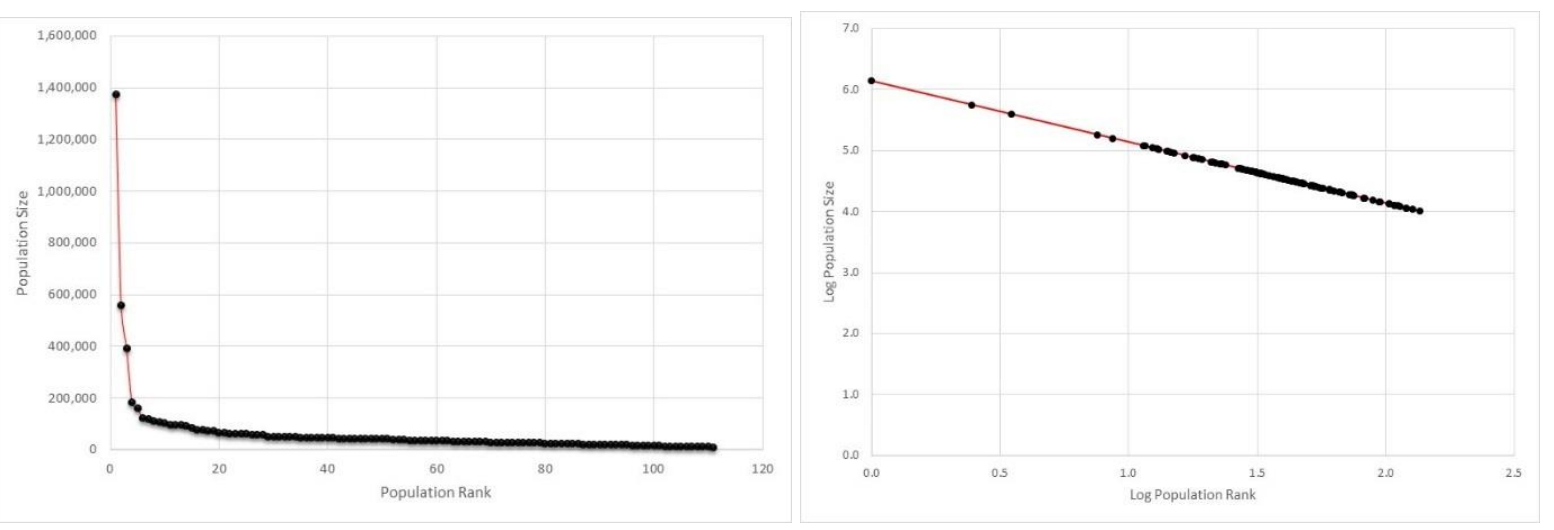

The dynamics of rural-urban transition are even obvious in four districts which are taken as cases in this research. Boyolali, Magelang, Klaten and Semarang have developed significantly from rural region into urban region in the last two decades (Figure 8). The transformation from rural to urban in the case regions has more or less help creating a more balanced urban system both within every single region and in the entire region of Joglosemar. Handayani (2013) argues that the shift from rural to urban in Central Java is mostly caused by industrialization process which takes place not only in larger urban centers but also in smaller urban areas. This has led to the growing number of smaller urban centers in the last two decades. In addition to that factor, Hinderink and Titus (2002) points out the important of development policy implemented by the government. In the case of Indonesia, 1990s saw a new paradigm adopted by the government which put kecamatan (sub-dictrict) as the basis for regional development through the implementation of Kecamatan Development Program (KDP). The program which was sponsored by the World Bank addressed poverty in rural areas by providing financial assistance for sub-district to build infrastructure as well as generating economic activities in order to alleviate poverty in rural areas (Guggenheim et al., 2004). It was a paradigm shift toward a more territorial approach rather than functional approach (see Hinderink \& Titus, 1988).

There are other important findings from the case of four districts. It seems that the role of road network as the main driver of development remains irreplaceable. New smaller urban centers mostly develop along the road network, although there are some towns which are quite remote. This confirms old conception that the existence of transport network plays important role in forming urban system in a region. The case from four districts also indicates that new small towns have functioned as transport hub or transit center from rural hinterland to larger urban areas. This connection has formed particular urban-rural linkages within the urban system of Joglosemar region. 
Figure 8. Small Cities Development in Joglosemar Region 1990-2010 (Authors, 2016)

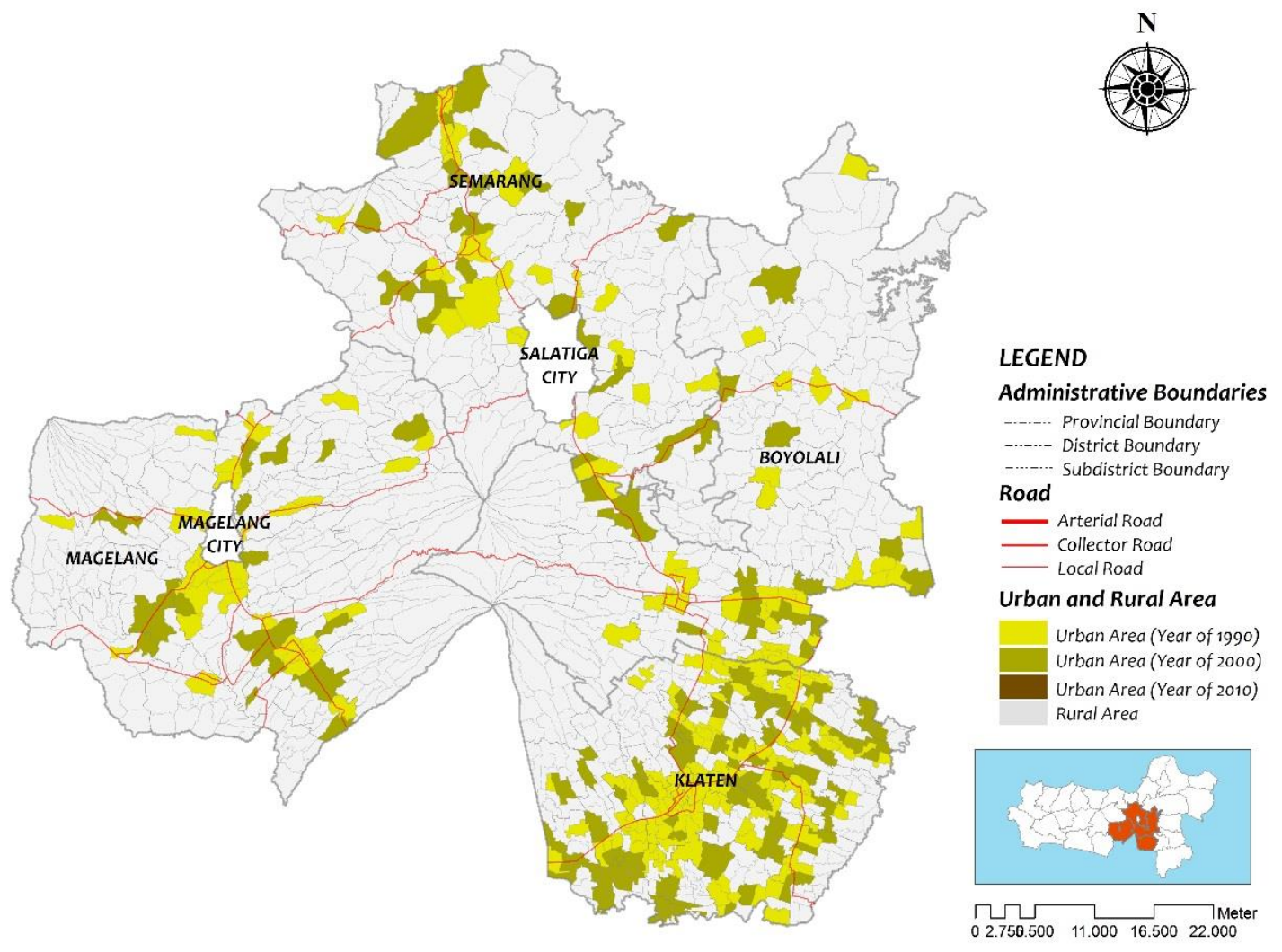

\section{CONCLUSION}

Urbanization process in Central Java region has been tremendous in the last two decades. This process has transformed the predominantly rural region in 1980s into urban region. The rapid growth of urban population forms some observable pattern which different to the national urbanization pattern. While there are common spatial patterns such as the importance of coastal region to the urbanization process and the role of larger urban centers in the urban growth, the emergence of smaller centers has also contributed to the process. Not only do the smaller urban centers grow significantly, they also have contributed to form more balanced urban system which is characterized by lower urban primacy and normal rank-size of the urban system. This situation would lead to a sustainable pattern of urbanization in the future for the corresponding region.

\section{ACKNOWLEDGMENTS}

Some parts of this research were done by funding assistance from the Department of Urban and Regional Planning, Diponegoro University, Semarang. The authors would like to appreciate and thank to the department.

\section{REFERENCES}

Armstrong, W., \& McGee, T. G. (1985). Theatres of accumulation: studies in Latin American and Asian urbanisation. London: Methuen.

Berry, B. J. L. (1961). City size distributions and economic development. Economic Development and Cultural Change, 573-588.

Berry, B. J. L. (1964). Cities as systems within systems of cities. Papers in Regional Science, 13(1), 147-163.

Bhagat, R. B., \& Mohanty, S. (2009). Emerging pattern of urbanization and the contribution of migration in urban growth in India. Asian Population Studies, 5(1), 5-20. 
Champion, T., \& Hugo, G. (2004). New forms of urbanization: beyond the urban-rural dichotomy. Ashgate Publishing Ltd.

Dix, G. (1986). Small cities in the world system. Habitat International, 10(1-2), 273-282.

Evans, J. (1984). The growth of urban centres in Java since 1961. Bulletin of Indonesian Economic Studies, 20(1), 44-57.

Fang, C., \& Yu, D. (2016). Spatial Pattern of China's New Urbanization. In China's New Urbanization (pp. 179-232). Springer.

Firman, T. (1992). The spatial pattern of urban population growth in Java, 1980--1990. Bulletin of Indonesian Economic Studies, 28(2), 95-109.

Firman, T. (1998). The restructuring of Jakarta Metropolitan Area:: A "global city" in Asia1An earlier version of this paper was presented to the Fourth International Congress of Asian Planning Schools Association (APSA) organized by the Department of Regional and City Planning, Institute of Technology Bandung, 2--4 September 1997 in Bandung, Indonesia. 1. Cities, 15(4), 229-243.

Firman, T. (2003). The spatial pattern of population growth in Java, 1990--2000: Continuity and change in extended metropolitan region formation. International Development Planning Review, 25(1), 53-66.

Firman, T. (2004). Demographic and spatial patterns of Indonesia's recent urbanisation. Population, Space and Place, 10(6), 421-434.

Firman, T. (2009). The continuity and change in mega-urbanization in Indonesia: A survey of Jakarta-Bandung Region (JBR) development. Habitat International, 33(4), 327-339.

Firman, T., \& Dharmapatni, I. A. I. (1994). The challenges to sustainable development in Jakarta metropolitan region. Habitat International, 18(3), 79-94.

Firman, T., Kombaitan, B., \& Pradono, P. (2007). The dynamics of Indonesia's urbanisation, 1980--2006. Urban Policy and Research, 25(4), 433-454.

Geertz, C. (1963). Peddlers and princes: Social development and economic change in two Indonesian towns (Vol. 318). University of Chicago Press.

Geertz, C. (1965). The social history of an Indonesian town. Mit Pr.

Giyarsih, S. R. (2010). Pola Spasial Transformasi Wilayah di Koridor Yogyakarta-Surakarta.

Guggenheim, S., et al. (2004). Indonesia's Kecamatan Development Program: A large-scale use of community development to reduce poverty. In Scaling Up Poverty Reduction: A Global Learning Process and Conference. Shanghai, May (pp. 25-27).

Guilmoto, C. Z., \& Jones, G. W. (2015). Contemporary Demographic Transformations in China, India and Indonesia (Vol. 5). Springer.

Handayani, W. (2013). Rural-Urban Transition in Central Java: Population and Economic Structural Changes Based on Cluster Analysis. Land, 2(3), 419-436. http://doi.org/10.3390/land2030419

Hinderink, J., \& Titus, M. (2002). Small towns and regional development: Major findings and policy implications from comparative research. Urban Studies, 39(3), 379-391.

Hinderink, J., \& Titus, M. J. (1988). Paradigms of regional development and the role of small centres. Development and Change, 19(3), 401-423.

Kasarda, J. D., \& Crenshaw, E. M. (1991). Third world urbanization: Dimensions, theories, and determinants. Annual Review of Sociology, 467-501.

Lo, F.-C., Salih, K., \& Douglass, M. (1981). Rural-urban transformation in Asia. Rural-Urban Relations and Regional Development, 7-43.

McGee, T. G. (1971). The urbanization process in the third world. London: G. Bell and Sons, Ltd.

McGee, T. G. (1989). Urbanisasi or kotadesasi? Evolving patterns of urbanization in Asia. Urbanization in Asia: Spatial Dimensions and Policy Issues, 108.

McGee, T. G. (1991). The Emergence of Desakota Regions in Asia: Expanding a Hypothesis. The Extended Metropolis Settlement Transition in Asia, Honolulu: University of Hawaii, 3-26.

McGranahan, G., \& Satterthwaite, D. (2014). Urbanisation: Concepts and Trends. IIED.

Meyer, D. R. (1986). System of cities dynamics in newly industrializing nations. Studies in Comparative International Development, 21(1), 3-22.

Milone, P. D. (1964). Contemporary urbanization in Indonesia. Asian Survey, 4(8), 1000-1012.

Milone, P. D. (1966). Urban areas in Indonesia: administrative and census concepts (Vol. 10). Institute of International Studies, University of California.

Mulyana, W. (2014). Rural-Urban Linkages: Indonesia Case Study. 
Nas, P. J. M. (1989). Town and countryside in Indonesia: A sceptic's view. Sojourn: Journal of Social Issues in Southeast Asia, 20-33.

Nas, P. J. M. (2003). The Indonesian town revisited (Vol. 1). LIT Verlag Münster.

Pacione, M. (2009). Urban geography: A global perspective. Routledge.

Potter, R. B., \& Lloyd-Evans, S. (2014). The city in the developing world. Routledge.

Rietveld, P. (1988). Urban Development Patterns in Indonesia 1. Bulletin of Indonesian Economic Studies, 24(1), 73-95.

Roberts, B. H. (2014). Managing systems of secondary cities. Policy Reponses in International.

Rondinelli, D. A. (1983). Dynamics of growth of secondary cities in developing countries. Geographical Review, 42-57.

Rotgé, V. L., Bagoes Mantra, I., Rijanta, R. (2000). Rural-urban integration in Java: consequences for regional development and employment. Ashgate Publishing Ltd.

Rutz, W. (1987). Cities and towns in Indonesia: their development current positions and functions with regard to administration and regional economy. Berlin Germany Federal Republic of Gebruder Borntraeger 1987.

Titus, M. J. (1991). A structural model for analysing production relations and regional functions of small towns in Central Java. Tijdschrift Voor Economische En Sociale Geografie, 82(4), 266-281.

United Nations. (2015). World Urbanization Prospects 2014: Highlights. United Nations Publications.

Wertheim, W. F. (1959). The Indonesian Town: Studies in Urban Sociology. Ekistics, 7(41), 238-241.

Wouden, A. A. (1997). Three small towns in Central Java. Netherlands Geographical Studies, 221.

Yunus, H. S. (2005a). Klasifikasi kota. Pustaka Pelajar.

Yunus, H. S. (2005b). Manajemen kota: perspektif spasial. Pustaka Pelajar. 